\title{
HPLC-PDA METHOD FOR THE QUANTIFICATION OF PARACETAMOL IN PLASMA: APPLICATION TO PK/PD STUDIES WITH ARTHRITIC RATS
}

\author{
ADRIANA MIRIAM DOMÍNGUEZ-RAMÍREZa, FRANCISCO JAVIER LÓPEZ-MUÑOZ ${ }^{b}$, JOSÉ RAÚL MEDINAa*, MARCELA \\ HURTADO ${ }^{a}$, GEORGINA ALARCÓN ÁNGELES ${ }^{\mathrm{a}}$, ADRIANA DESIREE PINEDA ${ }^{\mathrm{a}}$, LUIS ALFONSO MORENO-ROCHA ${ }^{\mathrm{a}}$
}

aDepartamento de Sistemas Biológicos, Universidad Autónoma Metropolitana-Xochimilco, México, bDepartamento de Farmacobiología, Cinvestav-Sede Sur, México

Email: rmlopez@correo.xoc.uam.mx

Received: 15 Feb 2017 Revised and Accepted: 31 Mar 2017

\section{ABSTRACT}

Objective: To develop and validate an easy, rapid, sensitive and selective high-performance liquid chromatography with photodiode diode-array (HPLC-PDA) detection method for quantification of paracetamol and to demonstrate its application in a pharmacokinetic-pharmacodynamic study with arthritic rats.

Methods: Paracetamol was separated from plasma samples (50-100 $\mu \mathrm{l}$ ) by a single protein precipitation step, prior to HPLC-PDA detection. The separation was performed on a Knauer Eurospher II, $C_{18}$ column $5 \mu \mathrm{m}, 150 \times 4.6 \mathrm{~mm}$. The mobile phase comprised a mixture of water: methanol (75:25) and the flow rate was $1.1 \mathrm{ml} / \mathrm{min}$. The detection wavelength was set at $245 \mathrm{~nm}$. All analyses were carried out at room temperature $\left(25{ }^{\circ} \mathrm{C}\right)$. Pharmacodynamics data were obtained with a gout-type pain model in rats.

Results: The method was linear within a range of $0.2-200 \mu \mathrm{g} / \mathrm{ml}\left(\mathrm{R}^{2} \geq 0.99\right)$. The intra-day and inter-day precision and accuracy expressed as coefficient of variation and relative error, respectively were below $10 \%$. The lower limit of quantification was $0.2 \mu \mathrm{g} / \mathrm{ml}$. Plasma samples were stable at least for $5 \mathrm{w}$ at $-20^{\circ} \mathrm{C}$.

Conclusion: The validated method is sensitive, precise, accurate and specific as other more complex high-performance liquid chromatographic methods coupled to mass spectrometry (HPLC-MS), using small plasma samples (50-100 $\mu$ l) and with a short time analysis (<5 min). The method was successfully applied to a pharmacokinetic-pharmacodynamic study of paracetamol in arthritic rats.

Keywords: Paracetamol, HPLC-PDA, Validation, Pharmacokinetic-pharmacodynamic, Arthritic rats

(C) 2017 The Authors. Published by Innovare Academic Sciences Pvt Ltd. This is an open access article under the CC BY license (http://creativecommons.org/licenses/by/4.0/) DOI: http://dx.doi.org/10.22159/ijpps.2017v9i5.17746

\section{INTRODUCTION}

Paracetamol is a non-steroidal anti-inflammatory drug (NSAID) with antipyretic properties and weak anti-inflammatory effect, commonly used for the relief of mild to moderate pain. Paracetamol is metabolized by microsomal enzymes in the liver, with $85-90 \%$ of the drug undergoing glucuronidation and sulfation to inactive metabolites that are eliminated in the urine as paracetamol glucuronide, PG (55\%) and paracetamol sulfate, PS (35\%). A smaller amount is conjugated with cysteine and mercapturic acid and only about $5 \%$ of the drug is eliminated unchanged in the urine. Total urinary recovery of paracetamol in $24 \mathrm{~h}$ has reported to be 71.5 $95 \%$, as free and/or conjugated [1]. Metabolism pathways of paracetamol are common in man and rats, however, rats excrete PS more than PG [2]. The elimination half-life of paracetamol is reported to be between 1.9 and $4.3 \mathrm{~h}$, in both species $[1,3]$.

The pharmacokinetics and pharmacodynamics of NSAIDs alone or in combination with opioid drugs (morphine or tramadol), or additives (caffeine) have been previously studied in order to investigate the mechanism involved in the response of them under different conditions (i.e. chronic vs. acute administration). In such case, it is necessary to follow blood sample at the same time as the effect is measured. As repeated blood sampling is required in pharmacokinetic-pharmacodynamics studies in small species (rats), it is necessary to utilize a sensitive and selective method and reduce the total volume of plasma extracted from the animals in order to avoid serious impairment to its physiological state.

The pharmacokinetics of paracetamol in arthritic rats after oral administration was reported [4] with a previously published highperformance liquid chromatography (HPLC) method [5]. However this method utilizes $500 \mu \mathrm{l}$ of plasma sample and $5 \mathrm{ml}$ of ethyl acetate for drug extraction and evaporation of solvent before injection of the dissolved residue. HPLC with ultraviolet/visible (UV/Vis) and electrochemical detection or nuclear magnetic resonancemass spectrometry, high-performance thin-layer chromatography, gas chromatography and capillary electrophoresis have been extensively used for the quantification of paracetamol and its metabolites in biological fluids [5-7]. However, most of this methods use large plasma samples (0.2-1.0 ml), multiple liquid-liquid extraction and evaporation steps $[5,8]$, a large volume of the extraction solvent $[3,5,9,10]$, short concentration intervals or long-time analysis $[10,11]$.

Most methods utilize liquid-liquid extraction for sample preparation, removing plasma proteins simultaneously. Protein precipitation has also been carried out by the addition of acetonitrile, methanol, perchloric acid, trichloroacetic acid, ethyl acetate or diethyl ether $[9,12,13]$. Solidphase extraction methods (SPE), including $\mathrm{C}_{18}$ Sep-Pak cartridges for the separation of paracetamol, acetylsalicylic and caffeine [11] and the simultaneous determination of paracetamol and dextropropoxyphene from human plasma have also been reported [3]. However, most of these methods involve elution, evaporation and reconstitution steps and are long-time consuming procedures. Table 1 includes the main characteristics of some reported HPLC methods for quantification of paracetamol in small plasma samples.

Up to this moment, none of the previously published methods fulfills the requirements to develop a pharmacokinetic-pharmacodynamics study of paracetamol in rats, so the aim of the present research was to develop and validate a rapid, easy, selective and reliable HPLC isocratic method with photo-diode-array (PDA) detection, using a single protein precipitation step, for the quantification of paracetamol in a small volume of plasma $(50-100 \mu \mathrm{l})$. The potential importance of the assay was demonstrated by the application of this method to a pharmacokinetic-pharmacodynamics study after oral administration of paracetamol to arthritic rats, allowing simultaneous blood sampling and measurement of antinociceptive effect in the same animal. 
Table 1: Published chromatographic methods for paracetamol quantification in small plasma samples

\begin{tabular}{|c|c|c|c|c|c|}
\hline Plasma sample preparation & Method & Mobile phase & $\begin{array}{l}\text { Run time } \\
\text { (min) }\end{array}$ & $\begin{array}{l}\text { Concentration range } \\
\text { Recovery, Precision } \\
\text { \& Accuracy }\end{array}$ & Reference \\
\hline $\begin{array}{l}200 \mu \mathrm{l}\left(\mathrm{SPE}^{\mathrm{a}}\right) \\
\text { Elution } \\
\text { Solvent Evaporation }\end{array}$ & HPLC-UV & $\begin{array}{l}\text { Gradient Elution } \\
1 \text { to } 85 \% \text { ACN: Water }\end{array}$ & 14 & $\begin{array}{l}\text { Range: } 0.1-1 \mu \mathrm{g} / \mathrm{ml} \\
\text { Recovery: } 73.7 \% \\
\text { CV: NRd; RE: NR } \\
\text { LLOQ: } 0.15 \mu \mathrm{g} / \mathrm{ml}\end{array}$ & [11] \\
\hline $\begin{array}{l}100 \mu \mathrm{l}\left(\mathrm{PP}^{\mathrm{b}}\right) \\
+100 \mu \mathrm{l} \mathrm{H} \mathrm{O} \mathrm{O} \\
+10 \mu \mathrm{HClO}_{4}(30 \%)\end{array}$ & HPLC-UV & $\begin{array}{l}\text { Isocratic Elution } \\
\mathrm{KH}_{2} \mathrm{PO}_{4} 0.1 \mathrm{M} \text { : Isopropanol: THF } \\
(100: 1.5: 0.1)\end{array}$ & 22 & $\begin{array}{l}\text { Range: } 0.06-30 \mu \mathrm{g} / \mathrm{ml} \\
\text { Recovery }>95 \% \\
\text { CV<2.97 \%; RE<7.5 \% } \\
\text { LLOQ: } 0.06 \mu \mathrm{g} / \mathrm{ml}\end{array}$ & [20] \\
\hline $\begin{array}{l}500 \mu \mathrm{l}\left(\mathrm{LLE}^{\mathrm{c}}\right) \\
+50 \mu \mathrm{l} \mathrm{MeOH} / \mathrm{H}_{2} \mathrm{O}(1: 1) \\
+3 \mathrm{ml} \text { Ethyl acetate } \\
\text { Solvent evaporation }\end{array}$ & LC-MS-MS & $\begin{array}{l}\text { Isocratic Elution } \\
\text { MeOH: ACN: } 1 \% \text { Formic acid } \\
(60: 20: 20)\end{array}$ & 2.5 & $\begin{array}{l}\text { Range: } 0.02-10 \mu \mathrm{g} / \mathrm{ml} \\
\text { Recovery }<70 \% \\
\text { CV }<14.5 \% ; \mathrm{RE}<7.3 \% \\
\text { LLOQ: } 0.02 \mu \mathrm{g} / \mathrm{ml}\end{array}$ & {$[21]$} \\
\hline $\begin{array}{l}100 \mu \mathrm{l}(\mathrm{PP}) \\
+100 \mu \mathrm{l} \text { ACN } \\
\text { Centrifugation (twice) }\end{array}$ & HPLC-UV & $\begin{array}{l}\text { Isocratic Elution } \\
\text { ACN: } \mathrm{H}_{2} \mathrm{O} \\
(12: 88)\end{array}$ & 8 & $\begin{array}{l}\text { Range: } 0.25-200 \mu \mathrm{g} / \mathrm{ml} \\
\text { Recovery: } 99 \% \\
\text { CV<5 \%; RE<6 \% } \\
\text { LLOQ: } 0.43 \mu \mathrm{g} / \mathrm{ml}\end{array}$ & [13] \\
\hline $\begin{array}{l}50 \mu \mathrm{l}(\mathrm{PP}) \\
+\mathrm{MeOH} / \mathrm{EtOH}(1: 1) \\
\text { Solvent evaporation }\end{array}$ & $\begin{array}{l}\text { UHPLC- } \\
\text { MS/MS }\end{array}$ & $\begin{array}{l}\text { Gradient Elution } \\
5 \text { mM Ammonium } \\
\text { Acetate buffer (pH 3.75) }\end{array}$ & 18 & $\begin{array}{l}\text { Range: } 0.02-10 \mu \mathrm{g} / \mathrm{ml} \\
\text { Recovery: } 90.3-109 \% \\
\text { CV<12 \%; } \mathrm{RE}<12 \% \\
\text { LLOQ: } 0.02 \mu \mathrm{g} / \mathrm{ml}\end{array}$ & [18] \\
\hline $\begin{array}{l}100 \mu \mathrm{l}(\mathrm{PP}) \\
+300 \mu \mathrm{l} \text { ACN: propylene } \\
\text { glycol (9:1) }\end{array}$ & $\begin{array}{l}\text { HPLC- } \\
\text { MS/MS }\end{array}$ & $\begin{array}{l}\text { Isocratic Elution } \mathrm{ACN}: \mathrm{MeOH}: \\
\text { Aq. } 0.0875 \% \text { formic acid } \\
(4: 4: 92)\end{array}$ & 6.5 & $\begin{array}{l}\text { Range: } 0.01-30 \mu \mathrm{g} / \mathrm{ml} \\
\text { Recovery: } 93 \% \\
\text { CV<15 \%; RE<15\% } \\
\text { LLOQ: } 0.01 \mu \mathrm{g} / \mathrm{ml}\end{array}$ & [10] \\
\hline $\begin{array}{l}300 \mu \mathrm{l}(\mathrm{LLE}) \\
+5 \mathrm{ml} \text { ethyl acetate } \\
\text { Solvent evaporation }\end{array}$ & HPLC-UV & $\begin{array}{l}\text { Isocratic Elution } \\
10 \mathrm{mM} \text { phosphate buffer }(\mathrm{pH} 7.5) \text { : } \\
\text { ACN }(70: 30)\end{array}$ & 12 & $\begin{array}{l}\text { Range: } 0.1-40 \mu \mathrm{g} / \mathrm{ml} \\
\text { Recovery: } 94 \% \\
\text { CV<7 \%; RE<6 \% } \\
\text { LLOQ: } 0.1 \mu \mathrm{g} / \mathrm{ml}\end{array}$ & [19] \\
\hline $\begin{array}{l}25 \mu \mathrm{l}(\mathrm{PP}) \\
+400 \mu \mathrm{l} \mathrm{MeOH} \\
\text { Centrifugation } \\
\text { Solvent evaporation }\end{array}$ & $\begin{array}{l}\text { UPLC- } \\
\text { MS-MS }\end{array}$ & $\begin{array}{l}\text { Isocratic Elution } \\
\text { Aq. } 1 \% \text { Formic acid: } \mathrm{MeOH}(80 \text { : } \\
\text { 20) }\end{array}$ & 10 & $\begin{array}{l}\text { Range: } 0.25-20 \mu \mathrm{g} / \mathrm{ml} \\
\text { Recovery: } 72.4-105.9 \% \\
\text { CV<12 \%; RE<5\% } \\
\text { LLOQ: } 0.25 \mu \mathrm{g} / \mathrm{ml}\end{array}$ & [22] \\
\hline $\begin{array}{l}100 \mu \mathrm{l}(\mathrm{LLE}) \\
+ \text { methylter-butil ether: } \\
\text { dichlorometane:hexane. } \\
\text { Solvent evaporation }\end{array}$ & $\begin{array}{l}\text { HPLC- } \\
\text { MS-MS }\end{array}$ & $\begin{array}{l}\text { Isocratic Elution } \\
\text { Aqueous formic acid: ACN (3: 97) }\end{array}$ & NR & $\begin{array}{l}\text { Range: } 0.1-50 \mu \mathrm{g} / \mathrm{ml} \\
\text { Recovery: NR } \\
\text { CV: NR; RE: NR } \\
\text { LLOQ: } 0.1 \mu \mathrm{g} / \mathrm{ml}\end{array}$ & [24] \\
\hline $\begin{array}{l}50 \mu \mathrm{l}(\mathrm{PP}) \\
+950 \mu \mathrm{l} \text { ACN } \\
\text { Dilution of supernatant } \\
\text { with mobile phase }(1: 5)\end{array}$ & $\begin{array}{l}\text { UPLC- } \\
\text { MS/MS }\end{array}$ & $\begin{array}{l}\text { Gradient elution } \\
90 \text { to } 10 \% \mathrm{H}_{2} \mathrm{O}(0.1 \% \text { formic } \\
\text { ácid): } \mathrm{ACN}\end{array}$ & 7 & $\begin{array}{l}\text { Range: } 1-100 \mu \mathrm{g} / \mathrm{ml} \\
\text { Recovery }>90 \% \\
\text { CV<8 \%; RE<16\% } \\
\text { LLOQ: } 1 \mu \mathrm{g} / \mathrm{ml}\end{array}$ & [23] \\
\hline $\begin{array}{l}100 \mu \mathrm{l}(\mathrm{PP}) \\
+150 \mu \mathrm{l} \mathrm{MeOH} / \mathrm{EtOH}(1: 1)\end{array}$ & HPLC-UV & $\begin{array}{l}\text { Gradient Elution } \\
\text { Acetate buffer (pH 4.5): ACN }\end{array}$ & 15 & $\begin{array}{l}\text { Range: } 0.5-100 \mu \mathrm{g} / \mathrm{ml} \\
\text { Recovery: } 92 \% \\
\text { CV<10 \%; } \mathrm{RE}<8 \% \\
\text { LLOQ: } 44.8 \mathrm{ng} / \mathrm{ml}\end{array}$ & [17] \\
\hline
\end{tabular}

aSPE=solid phase extraction; ${ }^{b P P}=$ protein precipitation; ${ }^{~ L L E=l i q u i d-l i q u i d ~ e x t r a c t i o n ; ~}{ }^{\mathrm{d} N R}=$ not reported

\section{MATERIALS AND METHODS}

\section{Materials}

Paracetamol, PG and p-aminophenol (PAP) were purchased from Sigma-Aldrich Co. (St. Louis, MO, USA). Methanol and acetonitrile were chromatographic grade (J. T. Baker, Mexico). All other reagents were analytical grade (E. Merck KGaA, Darmstadt, Germany). Chromatographic grade water $\left(18^{*}\right)$ was obtained by purifying distilled water in a Milli-Q filtration system (Millipore, Bedford, MA, USA). The mobile phase was filtered through 0.45 $\mu \mathrm{m}$ pore size nylon filters (Millipore, Bedford MA, USA) and degassed in an ultrasonic bath (Branson Ultrasonic Corp., Danbury CT, USA).

\section{Experimental equipment}

The chromatographic system consisted of a Knauer highperformance liquid chromatograph (Berlin, Germany) equipped with a Smartline pump 100, a Smartline PDA detector 2800 and a Smartline autosampler 3950. The chromatographic station Clarity Chrom V2.6. xx software was used for acquisition and processing of data. The separation was performed on a Knauer Eurospher II, $\mathrm{C}_{18}$ column $5 \mu \mathrm{m}, 150 \times 4.6 \mathrm{~mm}$ (Berlin, Germany). The mobile phase consisted of a mixture of water: methanol (75:25) degassed before use, and flow rate of $1.1 \mathrm{ml} / \mathrm{min}$. the detection wavelength was set at $245 \mathrm{~nm}$. All analyses were carried out at room temperature $\left(25^{\circ} \mathrm{C}\right)$.

\section{Animals}

Male Wistar rats [Crl: (WI) fBR] weighing 200-250 g from our own breeding (Universidad Autonoma Metropolitana-Xochimilco, Mexico), were used in this study. Rats were maintained under controlled environmental conditions at $22{ }^{\circ} \mathrm{C}$, under a $12 \mathrm{~h}$ light/dark cycle and provided with standard chow (Purina Laboratory Rodent Diet 5001) and water ad libitum. Twelve hours before the experiments food was withheld, but animals had free access to water. Experiments were performed during the light phase and animals were used only once. All experimental procedures were approved by the local Institutional Animal Care and Use Committee, in accordance with the Mexican federal regulations for the care and use of laboratory animals, NOM-062Z00-1999 (Mexican Ministry of Health) and with adherence to the Guide for Care and Use of Laboratory Animals, Washington, D. C. [15]. Protocol No. 16, January 29th, 2014. 


\section{Separation of plasma from rat blood}

Rat blood was collected by cardiac puncture from rats under isoflurane anesthesia, which was fasted overnight and had free access to water. Blood was transferred into heparinized glass tubes and centrifuged at $6000 \mathrm{rpm}$. Plasma was separated and stored at $-20{ }^{\circ} \mathrm{C}$ until further use.

\section{Preparation of calibration standards and quality control samples}

Stock solution of paracetamol $(1 \mathrm{mg} / \mathrm{ml})$ was prepared in methanol and stored at $4{ }^{\circ} \mathrm{C}$. Rat plasma calibration standards were prepared by spiking appropriate aliquots of the stock solution to drug-free rat plasma to give final concentrations of 0.2 to $200 \mu \mathrm{g} / \mathrm{ml}$. Quality control (QC) samples were prepared by adding the appropriate aliquots of the stock solutions to drug-free rat plasma. The QC samples were aliquoted $(50-100 \mu \mathrm{l})$ into polypropylene tubes and stored at $-20^{\circ} \mathrm{C}$ until analysis.

\section{Sample preparation procedure}

Plasma sample (50-100 $\mu \mathrm{l})$ was aliquoted into a microcentrifuge tube and spiked with $50 \mu \mathrm{l}$ of $10 \%$ zinc sulfate aqueous solution and $150 \mu \mathrm{l}$ of methanol for protein precipitation. The sample was vortexed for $1 \mathrm{~min}$, stored at $4{ }^{\circ} \mathrm{C}$ for $15 \mathrm{~min}$ and centrifuged at $14000 \mathrm{rpm}$ for $10 \mathrm{~min}$. Supernatant layer was separated of which $30 \mu \mathrm{l}$ were injected onto the column and peak areas were recorded.

\section{Method validation}

The method was validated according to the FDA guidelines for validation of bioanalytical methods [14].

\section{Selectivity}

To determine the selectivity of the method, drug-free rat plasma alone and spiked with known amounts of paracetamol, PG and PAP, were analyzed. In addition, plasma samples of rats administered with paracetamol in a single dose $(316.2 \mathrm{mg} / \mathrm{kg}$, p. o.) were analyzed to test the potential interference of endogenous compounds and other paracetamol metabolites.

\section{Calibration curves and linearity}

Three calibration curves from 0.2 to $200 \mu \mathrm{l}$, were determined. Standard calibration curves were generated by plotting paracetamol peak-area vs. drug plasma concentration. A least-squares linear regression analysis was performed to determine slope, intercept, determination coefficient $\left(\mathrm{R}^{2}\right)$ and linear regression analysis of variance. $A * P<0.05$ was considered significant.

\section{Intra-day and inter-day precision and accuracy}

For determination of intra-day variation sets of five replicates of QC samples of paracetamol at 1, 10 and $100 \mu \mathrm{g} / \mathrm{ml}$ and lower limit of quantification (LLQ) at $0.2 \mu \mathrm{g} / \mathrm{ml}$ along with a standard calibration curve were analyzed on the same day. For the inter-day precision, three replicates of each concentration level were analyzed along with a standard calibration curve in plasma on three different days. The coefficient of variation (CV) served as a precision measure. The CV should be less than 15\%, except at the LLQ where it should not exceed $20 \%$ [14].

The accuracy of the assay was determined on the above samples, by comparing the means of the measured concentrations with the nominal concentrations. The percentage deviation of the mean from true values expressed as a relative error (RE \%) served as a measure of accuracy. RE\% was calculated as follows:

$$
\mathrm{RE} \%=\frac{\text { (added concentration }- \text { recovered concentration) }}{\text { added concentration }} \times 100
$$

The mean value of $\mathrm{RE} \%$ should be within $\pm 15 \%$ of the nominal value, except for the LLQ where it should not exceed 20\% [14].

\section{Absolute recovery and LLQ}

The absolute recovery of the method was determined by extracting five replicates of QC samples at 1,10 , and $100 \mu \mathrm{g} / \mathrm{ml}$. The peak areas obtained were compared to those obtained after direct injection of non-extracted standard solutions in the mobile phase, at the same concentration levels.

The lower standard concentration of the calibration curve with a signal (peak-area) at least five times greater than the baseline noise was taken as the LLQ. Additionally, it was calculated using the equation: $10^{*}(\sigma / \mathrm{s})$. Where $\sigma$ is the standard deviation of the magnitude of the analytical response, and " $s$ " is the slope of the regression equation. The limit of detection (LOD) was calculated using $3.3^{*}(\sigma / \mathrm{s})$, where $\sigma$ and " $s$ " were already defined.

\section{Stability}

QC samples containing paracetamol at concentrations of 0.2 and 10 $\mu \mathrm{g} / \mathrm{ml}$ were prepared and analyzed by the previously described method in five replicates, at zero time and after stored at $-20{ }^{\circ} \mathrm{C}$ for five weeks. The absolute difference (AD \%) between mean values of concentrations obtained at two times was calculated as follows:

$\mathrm{AD} \%$

$$
=\frac{\text { (initial concentration } \left.- \text { concentration at } 5 \text { th week at }-20^{\circ} \mathrm{C}\right)}{\text { initial concentration }} \times 100
$$

The mean value of $\mathrm{AD}$ should be within $\pm 15 \%$ of the concentration at zero time [14].

\section{Pharmacokinetic-pharmacodynamic study of paracetamol}

One group of six rats was used in this study. The day of the study, under isoflurane anesthesia, rats were injected with $50 \mu \mathrm{l}$ of uric acid $(30 \%)$ into the right knee joint to induce nociception, and the caudal artery was cannulated with a PE-10 cannula (Clay Adams, Parsippany, NJ, USA) connected to a PE-50 cannula. The cannula was kept patent with a heparinized saline solution and stoppered with a needle. Rats were allowed to recover from anesthesia and a dose of $316.2 \mathrm{mg} / \mathrm{kg}$ of paracetamol (suspended in a $0.5 \%$ aqueous solution of carboxymethyl cellulose) was orally administered. Blood samples were withdrawn from the caudal artery at $0 \mathrm{~h}$ (before the administration of the drug) and at $0.25,0.5,1.0,1.5,2.0,2.5,3.0,3.5$ and $4.0 \mathrm{~h}$ after the administration of the drug and transferred to heparinized polypropylene tubes. The total volume of blood taken from each animal did not exceed $2.0 \mathrm{ml}$. The cannula was withdrawn and the animal was sacrificed after the last blood sample was taken. Plasma was separated by centrifugation at $3500 \mathrm{rpm}$ for $10 \mathrm{~min}$ at 4 ${ }^{\circ} \mathrm{C}$ and stored at $-20{ }^{\circ} \mathrm{C}$ until analysis. Plasma samples and a duplicate of QC samples at three concentrations levels were analyzed together with a standard calibration curve prepared the day of the analysis. Assays were acceptable if the accuracy of QC samples were within $\pm 15 \%$ of the nominal value.

Antinociception was determined before blood sampling times, using the "pain-induced functional impairment in rat" (PIFIR) model [16]. This model was specially designed for evaluation of arthritic gouttype pain in rats.

Pharmacokinetic parameters: maximum plasma concentration $\left(\mathrm{C}_{\max }\right)$, time to reach $\mathrm{C}_{\max }\left(\mathrm{t}_{\max }\right)$, area under the curve from zero time to $4 \mathrm{~h}\left(\mathrm{AUC}_{0-4}\right)$, area under the curve from zero time to infinite $\left(\mathrm{AUC}_{0-\infty}\right)$ and elimination constant rate $(\mathrm{K})$ were calculated by noncompartmental analysis using WinNonlin v. 4.1 (Pharsight, Mountain View, CA, USA). Pharmacodynamic parameters: maximum effect $\left(E_{\max }\right)$, time to reach $E_{\max }\left(t_{\max }\right)$ and cumulative antinociceptive effect during the whole observation period expressed as area under the effect-time curve (AUCE) were directly obtained from antinociceptive data. All AUC values were calculated by trapezoidal rule.

\section{RESULTS AND DISCUSSION}

\section{Chromatography and extraction procedure}

HPLC method with UV detection is a common method for the analysis of paracetamol in biological samples. However, many published papers describe the need for multiple extraction steps and/or complex chromatographic systems to ensure reproducibility and improve the analyte recovery (table 1). In this study, sample preparation is a modification of the proposed method of Soysa and Kolambage [13] for the analysis of paracetamol and its metabolites. 
In our proposed method, paracetamol is separated after precipitation of plasma proteins with $10 \%$ zinc sulphate aqueous solution and methanol with no previous sample preparation. Other precipitating solvents were initially tested as acetonitrile, diethyl ether, perchloric acid, trichloroacetic acid and methanol alone. The selected procedure gave cleaner supernatant and the highest extraction efficiency (99.7 to $108.1 \%$ ), which is comparable or higher than other published methods. Good sensitivity and adequate retention times were obtained with the isocratic system, water: methanol (75:25), and the reproducibility expressed as \%CV on the retention time and peak area $(n=5)$ was $0.2 \%$. Paracetamol, PG and PAP metabolites were eluted in a total run time of $5 \mathrm{~min}$.

\section{Method validation}

\section{Selectivity}

Chromatograms of drug-free rat plasma, plasma sample spiked with paracetamol, PG and PAP as well as plasma samples were taken after 1.5 and $4 \mathrm{~h}$ after a single dose of paracetamol (316.2 mg/kg, p. o.) to Wistar rats are shown in fig. 1. Drug-free plasma was found to be free of interfering peaks.

The proposed method allowed the adequate separation of paracetamol in a low plasma volume (50 to $100 \mu \mathrm{l}$ ) with a clean chromatogram, without the interference of endogenous compounds.
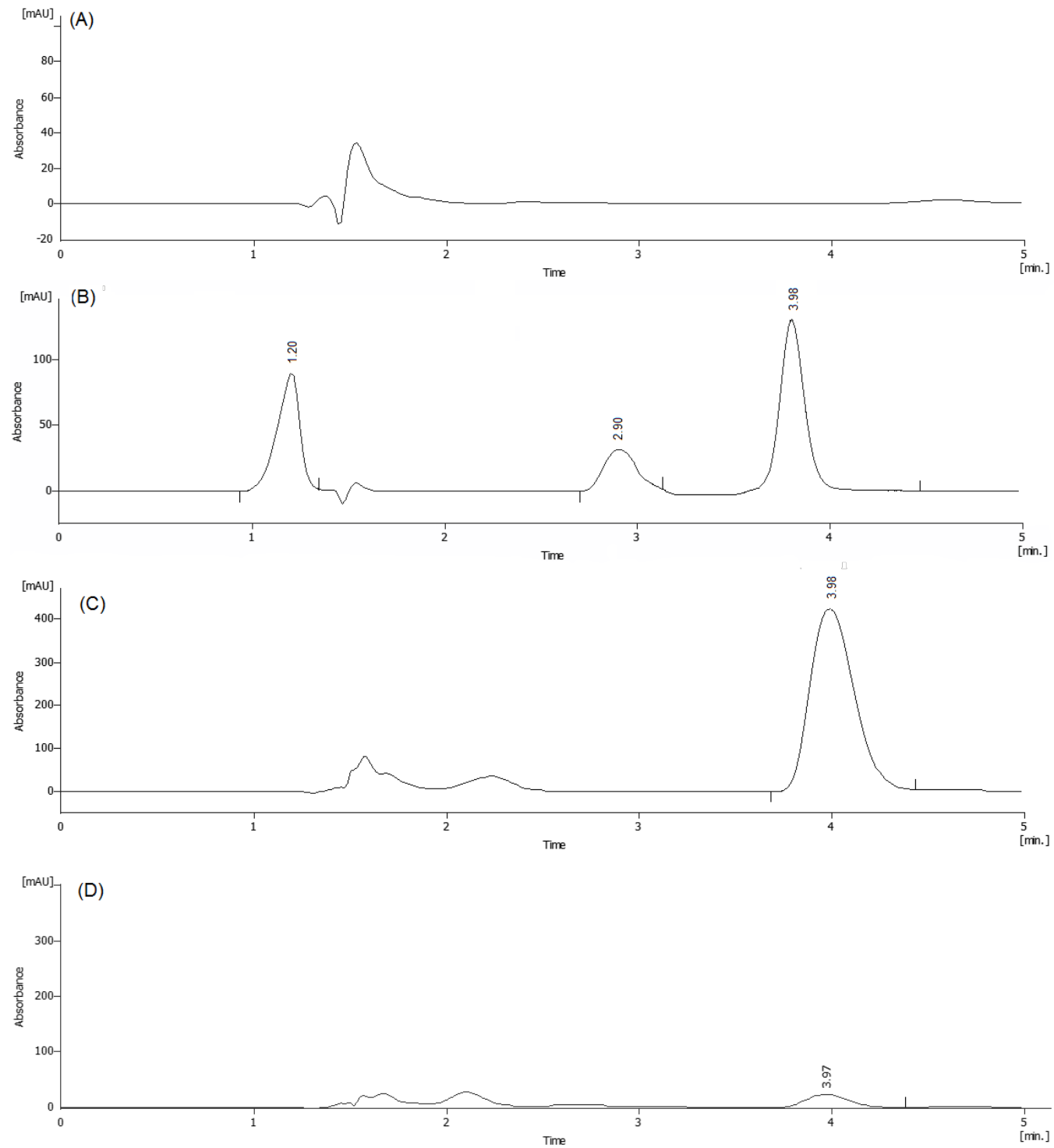

Fig. 1: Chromatograms of: (A) drug-free rat plasma; (B) rat plasma spiked with paracetamol glucuronide (1.20 min), p-aminophenol (2.90 min) and paracetamol ( $3.98 \mathrm{~min}$ ); (C) rat plasma that was taken $1.5 \mathrm{~h}$ after $\mathrm{p}$. o. administration of $316.2 \mathrm{mg} / \mathrm{kg}$ of paracetamol and (D) plasma sample that was taken $4.0 \mathrm{~h}$ after drug administration in the same rat

Separations of spiked plasma with PG and PAP, gave good resolution for the compounds peaks with good reproducibility and accuracy. No interfering signals were observed around the retention times of these compounds with only one-step extraction. The chromategraphic system employed gave satisfactory resolution for PG, PAP and paracetamol with retention times of $1.2,2.9$ and $3.98 \mathrm{~min}$, respectively. Resolution between PG and PAP was 5.73 and between PAP and paracetamol was 3.03. Plasma samples collected during the pharmacokinetic study did not show a signal of interference that could be attributed to endogenous compounds or other paracetamol biotransformation products.

\section{Linearity}

A linear relationship was found when paracetamol peak areas were plotted against drug plasma concentrations $(y=39.32 x+1.84$ $\left.\mathrm{R}^{2}=0.997\right)$. Linear regression was significant $\left({ }^{*} \mathrm{P}<0.05\right)$ for the concentration range studied $(0.2$ to $200 \mu \mathrm{g} / \mathrm{ml})$. For our purposes, this range was considered as the concentrations expected after the 
administration of doses needed to relieve arthritic pain in rats (10 to $316 \mathrm{mg} / \mathrm{kg}$ ] $[4,17]$

\section{Precision and accuracy}

Table 2 shows a summary of intra-day and inter-day precision of the method. CV values were below 1.0 and $10.0 \%$ respectively, demonstrating the good precision of the method. The precision of the method is comparable or even better than other published methods that use a higher volume of plasma sample and/or more complex sample preparation and/or more complex chromatographic systems $[3,9,17-21]$

The intra-day RE values assessed by quintuplicate analysis of QC samples ranged from 2.97 to $9.92 \%$. Inter-day accuracy, assessed by the triplicate analysis of QC samples in three different days, gave RE values from 5.01 to $8.78 \%$. These results demonstrate the accuracy of the method.

Table 2: Intra-and inter-day precision and accuracy for paracetamol analysis of QC samples by HPLC-PDA method

\begin{tabular}{|c|c|c|c|c|c|c|c|}
\hline \multirow{2}{*}{$\begin{array}{l}\text { Intra-day }(n=5) \\
\text { Added }(\mu \mathrm{g} / \mathrm{ml})\end{array}$} & \multicolumn{7}{|c|}{ Inter-day (3 d, $n=9)$} \\
\hline & Recovered $(\mu \mathrm{g} / \mathrm{ml})$ & CV (\%) & RE (\%) & Added $(\mu \mathrm{g} / \mathrm{ml})$ & Recovered $(\mu \mathrm{g} / \mathrm{ml})$ & CV (\%) & RE (\%) \\
\hline 0.202 & 0.196 & 1.07 & 2.97 & 0.205 & 0.221 & 3.6 & 7.80 \\
\hline 1.120 & 1.160 & 0.90 & 3.57 & 1.002 & 0.914 & 3.2 & 8.78 \\
\hline 10.10 & 9.780 & 1.20 & 3.17 & 10.015 & 9.400 & 3.5 & 6.14 \\
\hline 100.25 & 90.310 & 0.94 & 9.92 & 100.150 & 95.130 & 3.2 & 5.01 \\
\hline
\end{tabular}

\section{Recovery and LLQ}

The best recovery after using different precipitating solvents was obtained with the addition of $10 \%$ zinc sulphate aqueous solution together with methanol.

Moreover, the cleanest supernatant was obtained with this method. Absolute recoveries, calculated by comparing peak areas from extracted samples with peak areas of non-extracted standards, were between 99.7 and $108.1 \%$ with a good precision $(\mathrm{CV}<4 \%)$, independently of the studied concentration (data not shown). Additionally, a SPE method was also proved, but the drug recovery was only about $84 \%$ (data not shown), which is near to other methods that utilize SPE [11].

In addition, the recovery obtained with the selected method was higher than others that use shorter concentration intervals [1, $18,22]$; UPLC-MS/MS methods with simple protein precipitation with acetonitrile [23] or larger volumes of plasma samples [11, $19,21,22]$; or at least two-step liquid-liquid extraction and evaporation $[10,18,22,24]$. Other of the advantages of this method is that it allows a high recovery of the analyte from the biological matrix $(>99 \%)$ and allows multiple samples to be processed in a short period of time.
Plasma concentrations of paracetamol can be accurately quantified up to $0.2 \mu \mathrm{g} / \mathrm{ml}$, with a $\mathrm{CV}$ and $\mathrm{RE}<15 \%$, this was the reason by it was considered as the LLQ. The LOD was $0.06 \mu \mathrm{g} / \mathrm{ml}$.

\section{Stability}

From the stability study, it was found that plasma samples containing 0.2 and $10 \mu \mathrm{g} / \mathrm{ml}$ of paracetamol were stable for at least five weeks at $-20{ }^{\circ} \mathrm{C}$, with an $\mathrm{AD}$ of 4.4 and $10.3 \%$, respectively. Furthermore, stock solutions of paracetamol in methanol, stored at $4^{\circ} \mathrm{C}$, were stable for at least two weeks. Samples in mobile phase were stable for $24 \mathrm{~h}$ at room temperature.

\section{Pharmacokinetic-pharmacodynamic study}

The validated HPLC-PDA method was used to analyze paracetamol pharmacokinetics in arthritic rats, after single oral administration of $316.2 \mathrm{mg} / \mathrm{kg}$ of the drug. QC samples in each analytical run were within $15 \%$ of the nominal value. No interfering peaks were found during the analysis of the samples. PG and PAP metabolites were not detected in plasma samples. The proposed method was validated only for paracetamol as it is known that only the parent drug shows antinociceptive activity. All concentrations were above the LLQ. Mean plasma paracetamol concentration vs. time data are shown in fig. 2 .

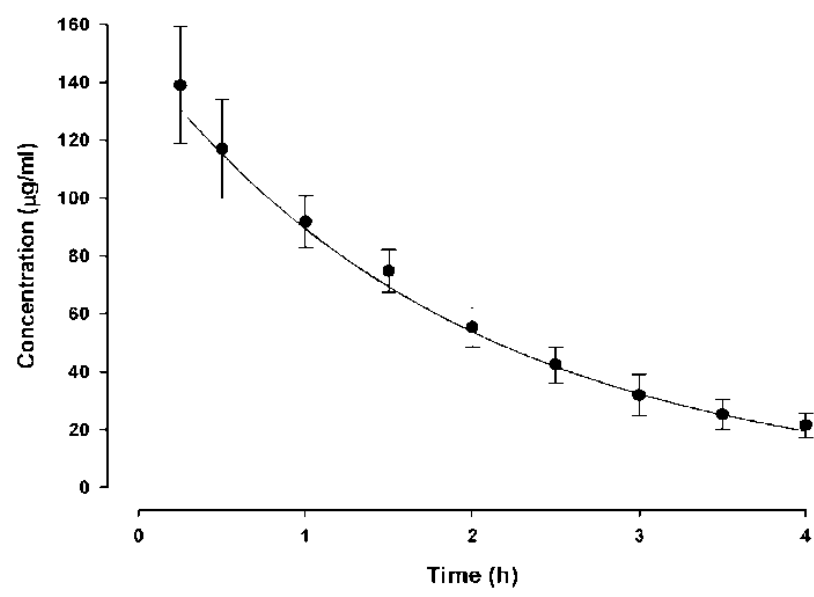

Fig. 2: Mean plasma concentration-time curve obtained after p. o. administration of $316.2 \mathrm{mg} / \mathrm{kg}$ of paracetamol to arthritic rats, (mean \pm SEM, $n=6$ )

Pharmacokinetic parameters were calculated by non-compartmental analysis from paracetamol concentration data. Results are summarized in table 3. Antinociceptive effect expressed as functionality index was plotted vs. time to construct the temporary course of the effect (data not shown). Pharmacodynamic parameters calculated from these data are also shown in table 3.
Pharmacokinetic and pharmacodynamic parameters values determined in the present study are comparable to those previously reported, under similar conditions [4].

This method might be applied to determine paracetamol plasma levels in pharmacokinetics-pharmacodynamics studies. 
Table 3: Pharmacokinetic and pharmacodynamic parameters obtained after oral administration of $316.2 \mathrm{mg} / \mathrm{kg}$ of paracetamol to arthritic rats

\begin{tabular}{ll}
\hline Parameter & Value $^{\mathbf{a}}$ \\
\hline Pharmacokinetic & \\
$\mathrm{C}_{\max }(\mu \mathrm{g} / \mathrm{ml})$ & $139.11 \pm 20.16$ \\
$\mathrm{t}_{\max }(\mathrm{h})$ & $0.38 \pm 0.13$ \\
$\mathrm{C}_{4 \mathrm{~h}}(\mu \mathrm{g} / \mathrm{ml})$ & $21.56 \pm 4.21$ \\
$\mathrm{AUC}_{0-4}(\mu \mathrm{gh} / \mathrm{ml})$ & $239.15 \pm 24.68$ \\
$\mathrm{AUC}_{0-\infty}(\mu \mathrm{gh} / \mathrm{ml})$ & $276.63 \pm 30.55$ \\
$\mathrm{~K}(1 / \mathrm{h})$ & $0.81 \pm 0.26$ \\
$\mathrm{t}_{1 / 2}(\mathrm{~h})$ & $1.17 \pm 0.22$ \\
$\mathrm{Cl} / \mathrm{F}(\mathrm{l} / \mathrm{kgh})$ & $1.21 \pm 0.12$ \\
$\mathrm{Vd} / \mathrm{F}(\mathrm{l} / \mathrm{kg})$ & $2.05 \pm 0.40$ \\
$\mathrm{Pharmacodynamic}$ & \\
$\mathrm{E}_{\max }(\%)$ & $74.75 \pm 4.67$ \\
$\mathrm{t}_{\max }(\mathrm{h})$ & $0.75 \pm 0.02$ \\
$\mathrm{E}_{4 \mathrm{~h}}(\%)$ & $32.26 \pm 10.37$ \\
$\mathrm{AUC}(\% \mathrm{~h})$ & $163.30 \pm 27.53$ \\
\hline
\end{tabular}

amean \pm SEM, $n=6$.

\section{CONCLUSION}

A reliable, simple and fast reversed-phase HPLC-PDA method for the quantification of paracetamol in small rat plasma samples was developed and validated. The method is simpler than many other published methods used for the quantification of paracetamol. It uses isocratic elution and avoiding salts buffers-organic solvent mixtures as the mobile phase. Excellent results for recoveries by simple protein precipitation were obtained, as well as intra-and inter-day precision along the entire concentration range studied.

The resolution of paracetamol from endogenous plasma components and paracetamol metabolites was satisfactory attained, as no other signals that could interfere with the quantification of the drug were observed. The present method proved to be useful for the determination of paracetamol plasma levels, in a small sample volume. So, a sufficient number of samples can be obtained from the same animal immediately after measuring the antinociceptive effect of the drug, in order to support pharmacokinetic-pharmacodynamic studies, without any impairment to its physiological state.

\section{ACKNOWLEDGEMENT}

We wish to thank J. Gutiérrez, K. de la Cruz, L. Oliva and J. Sabino for technical assistance.

\section{AUTHORS CONTRIBUTION}

A. M. Domínguez-Ramírez proposed the research protocol, supervised and directed the development and validation of the analytical method and the pharmacokinetic study, analysis of data and the writing of the paper; F. J. López-Muñoz had the direction of the pharmacodynamic study and revision of the article; J. R. Medina participated in the analysis of data and discussion of results, writing, organization and revision of the paper; M. Hurtado and G. Alarcón-Ângeles contributed with ideas on the modification of the analytical method and revision of the paper; L. A. Moreno-Rocha participated in the development of the pharmacodynamic-pharmacodynamic study, the statistical analysis of data and the elaboration of fig. and tables; A. D. Pineda assisted in the development of the analytical method.

\section{CONFLICT OF INTERESTS}

All authors have none to declare

\section{REFERENCES}

1. Alkhawaja B, Arafat T, Mallah E, Qinna N, Idkaidek N, Dayyih $\mathrm{WA}$, et al. Simultaneous determination of paracetamol and its metabolites in rat serum by HPLC method and its application supplement-drug pharmacokinetic interaction. Int J Pharm Anal 2014;39:1232-46.
2. Ishii M, Kanayama M, Esumi H, Ogawara KI, Kimura T, Higaki K. Pharmacokinetic analysis of factors determining elimination pathways for sulfate and glucuronide metabolites of drugs. I: studies by in vivo constant infusion. Xenobiotica 2002; 32:441-50.

3. Yin OQP, Lam SSL, Chow MSS. Simultaneous determination of paracetamol and dextropropoxyphene in human plasma by liquid chromatography/tandem mass spectrometry: application to clinical bioequivalence studies. Rapid Commun Mass Spectrom 2005;19:767-74.

4. Granados Soto V, Flores-Murrieta FJ, López-Muñoz FJ, Salazar LA, Villarreal JE, Castañeda-Hernández G. Relationship between paracetamol plasma levels and its analgesic effect in the rat. J Pharm Pharmacol1992;44:741-4.

5. Ameer B, Greenblatt DJ, Divoll M, Abernethy DR, Shargel L. High-performance liquid chromatographic determination of acetaminophen in plasma: single dose pharmacokinetic studies. J Chromatogr 1981;226:224-30.

6. Bose D, Durgbanshi A, Martinavarro-Domínguez A, CapellaPeiró ME, Carda-Broch S, Esteve-Romero JS, et al. Rapid determination of acetaminophen in physiological fluids by liquid chromatography using SDS mobile phase and ED detection. J Chromatogr Sci 2005;43:313-8.

7. Espinosa Bosch M, Ruiz Sánchez AJ, Sánchez Rojas F, Bosch Ojeda C. Determination of paracetamol: historical evolution review. J Pharm Biomed Anal 2006;42:291-321.

8. Oliveira EJ, Watson DG, Morton NS. A simple microanalytical technique for the determination of paracetamol and its main metabolites in blood spots. J Pharm Biomed Anal 2002;29:803-9.

9. Solangi A, Memon S, Mallah A, Memon N, Khuhawar MY, Bhanger MI. Determination of ceftriaxone, ceftizoxime, paracetamol, and diclofenac sodium by capillary zone electrophoresis in pharmaceutical formulations and in human blood serum. Turk J Chem 2010;34:921-33.

10. Tan QY, Zhu RH, Li HD, Wang F, Yan M, Dai LB. Simultaneous quantitative determination of paracetamol and its glucuronide conjugate in human plasma and urine by liquid chromatography coupled to electrospray tandem mass spectrometry: application to a clinical pharmacokinetic study. J Chromatogr B: Anal Technol Biomed Life Sci 2010; 893-894:162-7.

11. Abu-Qare AW, Abou-Donia MB. A validated HPLC method for the determination of pyridostigmine bromide, acetaminophen, acetylsalicylic acid and caffeine in rat plasma and urine. J Pharm Biomed Anal 2001;26:939-47.

12. Nagaralli BS, Seetharamappa J, Gowda BG, Melwanki MB. Liquid chromatographic determination of ceterizine hydrochloride and paracetamol in human plasma and pharmaceutical formulations. J Chromatogr B 2003;798:49-54. 
13. Soysa P, Kolambage S. Rapid HPLC/UV method for analysis of urinary and plasma/serum paracetamol concentrations. J Nat Sci Found Sri Lanka 2010;38:131-7.

14. Guidance for Industry "Bioanalytical Method Validation". U. S. Department of Health and Human Services, FDA, CDER; 2001 Available from: http://www.fda.gov/downloads/Drugs/ GuidanceComplianceRegulatoryInformation/Guidances/ucm0 70107.pdf [Last accessed on 10 Oct 2016]

15. Guide for Care and Use of Laboratory Animals. Eighth Ed. Washington DC: National Academic Press; 2011. Available from: http://grants.nih.gov/grants/olaw/Guide-for-the-Careand-Use-of-Laboratory-Animals.pdf [Last accessed on 10 Oct 2016]

16. López-Muñoz FJ, Salazar LA, Castañeda-Hernández G, Villarreal JE. A new model to assess analgesic activity: pain-induced functional impairment in the rat (PIFIR). Drug Dev Res 1993;28:169-75

17. Hilda A, Nashiru B, Kah-Hay Y. Simultaneous HPLC assay of paracetamol and sulfapyridine as markers for estimating gastrointestinal transit of amphotericin B-containing nanoparticles in rat plasma. J Bioequivalence Studies 2015; 1:104.

18. Tonoli D, Varesio E, Hopfgartner G. Quantification of acetaminophen and two of its metabolites in human plasma by ultra-high performance liquid chromatography-low and highresolution tandem mass spectrometry. J Chromatogr B 2012;904:42-50.

19. Gorain B, Choudhury H, Nandi U, Das A, Dan S, Pal TK. Development and validation of an HPLC method for simultaneous detection and quantification of paracetamol and etodolac in human plasma and its application to a pharmacokinetic study. JAOAC Int 2013;96:573-9.
20. Jensen LS, Valentine J, Milne RW, Evans AM. The quantification of paracetamol, paracetamol glucuronide and paracetamol sulphate in plasma and urine using a single high-performance liquid chromatography assay. J Pharm Biomed Anal 2004;34:585-93.

21. Liao $\mathrm{Q}$, Xie $\mathrm{Z}$, Pan $\mathrm{B}, \mathrm{Zhu} \mathrm{C}$, Yao $\mathrm{M}, \mathrm{Xu} \mathrm{X}$, et al. LC-MS-MS Simultaneous determination of paracetamol, pseudoephedrine and chlorpheniramine in human plasma: application to a pharmacokinetic study. Chromatographia 2008;67:687-94.

22. Gicquel T, Aubert J, Lepage S, Fromenty B, Morel I. Quantitative analysis of acetaminophen and its primary metabolites in small plasma volumes by liquid chromatography-tandem mass spectrometry. J Anal Toxicol 2013;37:110-6.

23. Cha J, Kim BK, Gwon M, Lee J, Ohk B, Kang WY, et al. Development and validation of a UPLC-MS/MS method for the quantification of acetaminophen in human plasma and its application to pharmacokinetic studies. Transl Clin Pharmacol 2016;24:30-6.

24. Devarakonda K, Morton T, Margulis R, Giuliani M, Barrett T. Pharmacokinetics and bioavailability of oxycodone and acetaminophen following single-dose administration of MNK795, a dual-layer biphasic IR/ER combination formulation, under fed and fasted conditions. Drug Des Dev Ther 2014;8:1125-34.

\section{How to cite this article}

- Adriana Miriam Domínguez-Ramírez, Francisco Javier LópezMuñoz, José Raúl Medina, Marcela Hurtado, Georgina Alarcqn Angeles, Adriana Desiree Pineda, Luis Alfonso Moreno-Rocha. HPLC-PDA method for the quantification of paracetamol in plasma: application to PK/PD studies with arthritic rats. Int J Pharm Pharm Sci 2017;9(5):233-239. 